\title{
Impact of disease-modifying antirheumatic drugs on vaccine immunogenicity in patients with inflammatory rheumatic and musculoskeletal diseases
}

\author{
Marcia A Friedman $\odot,{ }^{1}$ Jeffrey R Curtis $\odot{ }^{2}$ Kevin L Winthrop $\oplus^{1,3}$
}

\section{Handling editor Josef $S$ Smolen}

${ }^{1}$ Medicine, Oregon Health \& Science University, Portland, Oregon, USA

${ }^{2}$ Division of Clinical Immunology and Rheumatology, University of Alabama at Birmingham Department of Medicine, Birmingham, Alabama, USA ${ }^{3}$ School of Public Health, Oregon Health \& Science University, Portland, Oregon, USA

\section{Correspondence to}

Dr Marcia A Friedman, Medicine, Oregon Health \& Science University, Portland, OR 97239, USA; friedmam@ohsu.edu

Received 27 July 2021 Accepted 25 August 2021

Published Online First

7 September 2021
Check for updates

(C) Author(s) (or their employer(s)) 2021. No commercial re-use. See rights and permissions. Published by BMJ.

To cite: Friedman MA Curtis JR, Winthrop KL. Ann Rheum Dis

2021:80:1255-1265.

\section{ABSTRACT}

Patients with rheumatic diseases are at increased risk of infectious complications; vaccinations are a critical component of their care. Disease-modifying antirheumatic drugs may reduce the immunogenicity of common vaccines. We will review here available data regarding the effect of these medications on influenza, pneumococcal, herpes zoster, SARS-CoV-2, hepatitis $B$, human papilloma virus and yellow fever vaccines. Rituximab has the most substantial impact on vaccine immunogenicity, which is most profound when vaccinations are given at shorter intervals after rituximab dosing. Methotrexate has less substantial effect but appears to adversely impact most vaccine immunogenicity. Abatacept likely decrease vaccine immunogenicity, although these studies are limited by the lack of adequate control groups. Janus kinase and tumour necrosis factor inhibitors decrease absolute antibody titres for many vaccines, but do not seem to significantly impact the proportions of patients achieving seroprotection. Other biologics (interleukin-6R (IL-6R), IL-12/IL-23 and IL-17 inhibitors) have little observed impact on vaccine immunogenicity. Data regarding the effect of these medications on the SARS-CoV-2 vaccine immunogenicity are just now emerging, and early glimpses appear similar to our experience with other vaccines. In this review, we summarise the most recent data regarding vaccine response and efficacy in this setting, particularly in light of current vaccination recommendations for immunocompromised patients.

\section{INTRODUCTION}

Patients with inflammatory rheumatic diseases are at increased risk of vaccine-preventable infectious diseases. ${ }^{1-6}$ Vaccinations reduce the risks of infectious complications in patients with rheumatic disease, ${ }^{78}$ yet are under utilised. ${ }^{9}{ }^{10}$ While vaccinations are critically important, the drugs used to treat inflammatory diseases may impair responses to vaccines. This review addresses available data regarding the effect of disease-modifying anti-rheumatic drugs (DMARDs) on vaccine immunogenicity (table 1 ) and summarises vaccination recommendations made for this population (table 2).

Vaccine immunogenicity is typically measured as a surrogate for clinical vaccine efficacy. Interpreting and harmonising results from studies of vaccine immunogenicity are complicated by several factors. First, the arsenal of DMARD therapy is rapidly expanding with new drug classes and more drugs within each class, and these may have subtle yet important differences (eg, differences in Janus kinase (JAK)-inhibitor targets and JAK selectivity.) Second, recommended vaccines continue to change; pneumococcal and influenza vaccines frequently change, and we now have multiple critically important SARS-CoV-2 vaccines. Lastly, outcome measures (timing of response measurement, how response is measured, definitions of response ${ }^{11}$ ) and study design (control groups, concomitant methotrexate (MTX) or low-dose glucocorticoid therapy) are inconsistent across studies, making it difficult to parse out the true impact of the drug on vaccine immunogenicity or efficacy.

We will summarise here the available data evaluating the effect of DMARDs on vaccine immunogenicity, as well as to summarise current recommendations for how and when to vaccinate patients with rheumatic disease on DMARD therapy. While all vaccines are potentially important, we will focus on influenza, pneumococcus, herpes zoster, hepatitis B virus (HBV), tetanus, human papilloma virus (HPV) and yellow fever (YF) vaccines, as well as the newly emerging data for the SARS-CoV-2 vaccines (table 1). We will additionally review safety data regarding live vaccines (herpes zoster and YF) and newer highly immunogenic recombinant herpes zoster and SARS-CoV-2 vaccines.

\section{INFLUENZA VACCINATION \\ Background}

Intramuscular influenza vaccines are available as trivalent vaccines containing two strains of influenza A and one strain of influenza B, and quadrivalent vaccines, which contain an additional $\mathrm{B}$ strain. ${ }^{12} 13$ Two quadrivalent vaccines are currently recommended for adults age $\geq 65-$ a high-dose quadrivalent vaccine (Fluzone High-Dose) and an adjuvanted quadrivalent vaccine (Fluad Quadrivalent). ${ }^{12} 13$ The live attenuated intranasal influenza vaccine is contraindicated in patients taking biologics or other immunomodulatory therapies (eg, JAK inhibitors). Influenza vaccine efficacy is estimated using a surrogate of haemagglutinin inhibition titres. A titre of 1:40 is considered 'seroprotected' (as defined as 50\% vaccine efficacy).

\section{Effect of DMARD therapy of vaccine efficacy} Rituximab $^{14-21}$ and MTX ${ }^{14} 2223$ reduce influenza vaccine immunogenicity. Abatacept likely impairs immunogenicity though data are limited. ${ }^{24-26}$ Postvaccination antibody titres are lower in patients on tumour necrosis factor (TNF) ${ }^{142027-29}$ and JAK inhibitors, ${ }^{30}$ although the proportion of patients achieving seroprotection is similar to patients with 
Table 1 Impact of disease-modifying antirheumatic drugs on vaccine immunogenicity

\begin{tabular}{|c|c|c|c|c|c|c|c|}
\hline & Influenza & Pneumococcal & Herpes zoster & Hepatitis B & $\begin{array}{l}\text { Human } \\
\text { papilloma virus }\end{array}$ & Tetanus & SARS-CoV-2 (mRNA) \\
\hline TNF inhibitors & $\mathrm{OK}^{1416202728}$ & $\mathrm{OK}^{1456}$ & $\mathrm{OK}(\mathrm{ZVL})^{64}$ & $\downarrow^{103-105}$ & $\mathrm{OK}^{117132}$ & $\mathrm{OK}^{121124 *}$ & $0 K^{848588}$ \\
\hline Abatacept & $\downarrow^{2426}$ & $\downarrow^{4546}$ & & & & $\begin{array}{l}\mathrm{OK}(\mathrm{SQ})^{122} \\
\downarrow(\mathrm{IV})^{123}\end{array}$ & $\downarrow^{84}$ \\
\hline JAK inhibitor & $\mathrm{OK}^{30}$ & $\downarrow^{30}$ & & & & $\begin{array}{l}\text { OK (tofacitinib) }{ }^{120} \\
\downarrow \text { (baricitinib) }^{53}\end{array}$ & $\downarrow^{8284}$ \\
\hline IL-12/IL-23 inhibitor & $\mathrm{OK}^{32}$ & $\mathrm{OK}^{54}$ & & $\downarrow^{105}$ & & $\mathrm{OK}^{54}$ & $\mathrm{OK}^{82}$ \\
\hline IL-17 inhibitor & $\mathrm{OK}^{33-35}$ & $0 K^{55}$ & & & & $O K^{55}$ & $\mathrm{OK}^{84}$ \\
\hline
\end{tabular}

OK indicates no significant/meaningful effect on vaccine immunogenicity (may include reduction in absolute postvaccination titres if rates of protective titres are unchanged.) $\downarrow$ reduces vaccine immunogenicity. $\downarrow \downarrow$ significantly reduces vaccine immunogenicity. For OK, $\downarrow$ and $\downarrow \downarrow$ if no control group is available, data are compared with expected vaccine responses in the general population. Empty cells indicate lack of data.

IL, interleukin; JAK, Janus kinase; RZV, recombinant zoster vaccine; SQ, subcutaneous; TNF, tumour necrosis factor; ZVL, zoster vaccine live.

rheumatic disease not treated with these medications. Interleukin (IL)-6, IL-12/IL-23 and IL-17 inhibitors do not appear to impact the influenza vaccine ${ }^{31-35}$ (table 1$)$.

Influenza vaccination responses may be improved for rituximab $^{1621}$ and MTX ${ }^{22} 23$ treated patients by optimally timing the drug and vaccine. Timing the influenza vaccine 6-10 months after rituximab yielded modestly better results than $4-8$ weeks after rituximab (5/12 vs $1 / 11$ patients achieved seroprotection, $\mathrm{p}=0.108) .{ }^{21}$ In a randomised controlled trial, 316 patients with rheumatoid arthritis (RA) were randomised to take continuous MTX or to hold MTX for 2 weeks after influenza vaccine. Those who held MTX had higher rates of satisfactory vaccine response $(75.5 \%$ vs $54.5 \%, \mathrm{p}<0.001)$; however, lower doses of MTX $\leq 7.5 \mathrm{mg} /$ week did not show a significant improvement with MTX dose interruption. ${ }^{23}$ Post-hoc analyses found that MTX reduced vaccine response only in patients with high B cell activating factor (BAFF) levels, raising questions about whether these results are generalisable to all patients or only a subset with elevated BAFF (which is not routinely evaluated). ${ }^{36}$

Abatacept likely impairs influenza vaccine immunogenicity, though data are limited. ${ }^{24-26}$ Two studies of the pandemic 2009 influenza $\mathrm{A} / \mathrm{H} 1 \mathrm{~N} 1$ vaccine found that patients on abatacept had a substantially lower rate of seroconversion; in one study this rate was as low as 9\% compared with 69\% of controls $(\mathrm{p}=0.001) .{ }^{24}{ }^{26}$ However, an uncontrolled study of the trivalent 2011-2012 seasonal influenza vaccine found that $81.2 \%$ of patients on subcutaneous abatacept were able to mount protective antibody titres, ${ }^{25}$ which is only modestly reduced compared with general population rates (89\%-97\% for each influenza strain). ${ }^{37}$

Low-dose glucocorticoid use has not been shown to impact influenza vaccine response when added to other DMARD therapy. In a study of infliximab and influenza vaccine response, concomitant low-dose glucocorticoids (mean doses $5-10 \mathrm{mg} /$ day) were not found to impact influenza vaccine response. ${ }^{38}$ Similarly, low-dose prednisone (mean $8 \mathrm{mg} /$ day) in RA did not adversely affect influenza vaccine response in a multivariant regression analysis when evaluated alongside other DMARD therapy. ${ }^{27}$

\section{Recommendations}

Routine yearly influenza vaccines are recommended for all people aged 6 months or older. ${ }^{12} 39$ The European League Against Rheumatism (EULAR) and American College of Rheumatology (ACR) both recommend yearly intramuscular influenza vaccinations for all patients with RA. ${ }^{4041}$

High-dose influenza vaccines may be more effective in patients with rheumatic disease, ${ }^{42-44}$ although at this time the high-dose vaccine is recommended only for adults aged $\geq 65$. $^{12}$ A randomised study of 279 patients with RA found that those receiving the high-dose influenza vaccine were more likely to seroconvert (OR: 2.99, 95\% CI: 1.46 to 6.11 ); this effect was similar in patients on synthetic and biologic DMARDs. ${ }^{42}$

Rituximab-treated patients should ideally receive the influenza vaccine before initiating rituximab, or as long after the last dose of rituximab and 2-4 weeks before the next dose, ${ }^{41}$ as compatible with the influenza season. However, when this timing is not compatible with the influenza season, patients on rituximab may still be able to mount a T-cell response to the vaccination (although it is not known whether T-cell responses correlate with influenza protection). ${ }^{17}$ Patients on MTX can improve influenza vaccination responses by holding MTX for 2 weeks after vaccination, particularly for those on $\geq 15 \mathrm{mg} /$ week; holding MTX did not appear to increase disease activity measures, although this group had a small increase in the rate of flares $(5.1 \%$ vs $10.6 \%, p=0.07) .^{22} 23$

\section{PNEUMOCOCCAL VACCINATION Background}

Two pneumococcal vaccines are commonly used, pneumococcal conjugate vaccine 13-valent (PCV13) and pneumococcal polysaccharide vaccine 23-valent (PPSV23). PCV13 is conjugated to a diphtheria protein and is more immunogenic than the polysaccharide vaccine. Both PCV13 and PPSV23 vaccine immunogenicity is typically measured by postvaccination antibody titres against serotypes found in each vaccine, although the titre level chosen as 'protective' can be variable and is arbitrary, as no level of 'seroprotection' against most pneumococcal disease has been established. ${ }^{11}$

\section{Effect of DMARD therapy on vaccine efficacy}

As with most vaccines in the rheumatologic setting, studies have not been large enough to evaluate changes in efficacy related to DMARD usage. Immunogenicity outcomes are achievable in such studies, and it is clear that rituximab ${ }^{141845-47}$ and MTX $^{11} 14{ }^{48-51}$ reduce pneumococcal vaccine immunogenicity. JAK inhibitors 3553 and abatacept ${ }^{25} 4546$ appear to modestly 
Recommended modification of DMARD therapy relative to vaccine timing based on guidelines and best available evidence*, as

Vaccination recommendation compatible with disease activity

\begin{tabular}{|c|c|c|}
\hline Influenza & $\begin{array}{l}\text { Yearly quadrivalent vaccination for all patients. }{ }^{\dagger \S} \\
\text { Patients older than } 65 \text { should receive the high-dose quadrivalent } \\
\text { vaccine. } \\
\text { May consider high-dose vaccine for all immunocompromised } \\
\text { patients. }{ }^{\star * 244}\end{array}$ & $\begin{array}{l}\text { Rituximab: vaccinate before starting rituximab, or as long as possible after } \\
\text { the last dose (ideally } \geq 6 \text { months) and } 4 \text { weeks before the next dose. }{ }^{\S} \\
\text { MTX: consider holding for } 2 \text { weeks after vaccination. }{ }^{* 22} 23\end{array}$ \\
\hline Pneumococcal & $\begin{array}{l}\text { Recommended for all immunosuppressed patients. }{ }^{\dagger \uparrow} \\
\text { Give one dose of PCV13 followed by PPSV } 23 \text { at least } 8 \text { weeks } \\
\text { later. Give a second PPSV23 dose } 5 \text { years after the first PPSV23 }\end{array}$ & $\begin{array}{l}\text { Rituximab: vaccinate before starting rituximab, or as long as possible after } \\
\text { the last dose (ideally } \geq 6 \text { months) and } 4 \text { weeks before the next dose. } \\
\text { MTX: consider holding MTX for } 2 \text { weeks after vaccination. }{ }^{*}\end{array}$ \\
\hline
\end{tabular}

\begin{tabular}{|c|c|c|}
\hline Herpes zoster & $\begin{array}{l}\text { Recombinant zoster vaccine for adults over age } 50 .^{+\uparrow} \\
\text { Use live Zoster vaccine where recombinant is not available. } \\
\text { Consider in all high-risk patients with rheumatic disease. }{ }^{\dagger \S}\end{array}$ & $\begin{array}{l}\text { Rituximab: vaccinate before starting rituximab, or as long as possible after } \\
\text { the last dose (ideally } \geq 6 \text { months) and } 4 \text { weeks before the next dose. }\end{array}$ \\
\hline Hepatitis B & All non-immune adults at risk for HBV infection. ${ }^{\dagger \neq \S^{* *}}$ & $\begin{array}{l}\text { Rituximab: vaccinate before starting rituximab, or as long as possible after } \\
\text { the last dose (ideally } \geq 6 \text { months) and } 4 \text { weeks before the next dose. }\end{array}$ \\
\hline Human papilloma virus & $\begin{array}{l}\text { As per general population guidelines, especially for patients with } \\
\text { SLE. } .^{\ddagger \ddagger}\end{array}$ & $\begin{array}{l}\text { Rituximab: vaccinate before starting rituximab, or as long as possible after } \\
\text { the last dose (ideally } \geq 6 \text { months) and } 4 \text { weeks before the next dose. }\end{array}$ \\
\hline Tetanus & $\begin{array}{l}\text { As per general population and consider for all rituximab-treated } \\
\text { patients. }\end{array}$ & Rituximab: vaccinate before starting rituximab. ${ }^{\S}$ \\
\hline SARS-CoV-2 & All patients as per the general population. ${ }^{101}$ & $\begin{array}{l}\text { ACR guidance summary }{ }^{101} \text { : } \\
\text { Rituximab: as long as possible after the last dose, } 2-4 \text { weeks before the } \\
\text { next dose. } \\
\text { MTX: hold for } 1 \text { week after each mRNA dose; hold for } 2 \text { weeks after single- } \\
\text { dose vaccine. } \\
\text { Mycophenolate mofetil and JAK inhibitors: hold for } 1 \text { week after each } \\
\text { vaccine dose. } \\
\text { Abatacept subcutaneous: hold } 1 \text { week before and } 1 \text { week after the first } \\
\text { vaccine dose, no interruption for the second vaccine dose. } \\
\text { Abatacept intravenous: time the first vaccine dose } 4 \text { weeks after abatacept } \\
\text { and postpone next infusion by } 1 \text { week; no adjustment for the second vaccine } \\
\text { dose } \\
\text { Cyclophosphamide: time cyclophosphamide } 1 \text { week after each vaccine dose. } \\
\text { TNF, IL-6R, IL-1, IL-17, IL-12/23, IL-23, oral calcineurin inhibitors, } \\
\text { belimumab } \\
\text { apremilast, intravenous immune globulin (IVIG) and glucocorticoids }<20 \text { mg/ } \\
\text { day }{ }^{\dagger+} \text { : no modification. }\end{array}$ \\
\hline
\end{tabular}

\footnotetext{
*Authors' recommendations based on best available evidence.

†2021 Advisory Committee on Immunisation Practices recommendations. ${ }^{12}$

$\$ 2015$ American College of Rheumatology guideline for the treatment of rheumatoid arthritis. ${ }^{40}$

§2019 European League Against Rheumatism recommendations for vaccination in adult patients with autoimmune inflammatory rheumatic diseases. ${ }^{41}$

IPer CDC guidelines, adults with immunocompromising conditions were not included in initial clinical trials and therefore no recommendations regarding vaccination age for this population was made. However, this may change in the future.

**Risk factors include: persons at risk through sexual exposure (sex partners of hepatitis B surface antigen positive persons, sexually active persons not in a long-term monogamous relationship, persons seeking evaluation or treatment for a sexually transmitted disease, men who have sex with men), persons with a history of current or recent injection drug use, persons at risk for infection by percutaneous or mucosal exposure to blood (household contact or sexual partner who is hepatitis B surface antigen positive, resident or staff of a facility for the developmentally disabled, healthcare or public safety workers with anticipated risk for exposure to body fluids, patients with end-stage renal disease, persons with diabetes mellitus aged $<60$ or those over age 60 at the discretion of the treating physicians), travellers to endemic areas, patients with chronic liver disease or hepatitis $\mathrm{C}$ infection, incarcerated persons and patients with HIV.

t†Data published since guideline development suggests that lower doses of prednisone and belimumab may adversely impact the SARS-CoV-2 mRNA vaccine immunogenicity. ${ }^{84}$ ACR, American College of Rheumatology; CDC, Center for Disease Control; DMARD, disease-modifying antirheumatic drug; IL, interleukin; JAK, Janus kinase; MTX, methotrexate; PCV13, pneumococcal conjugate vaccine 13-valent; PPSV23, pneumococcal polysaccharide vaccine 23-valent; SLE, systemic lupus erythematosus; TNF, tumour necrosis factor.
}

reduce immunogenicity, while other biologics (TNF, IL-6, IL-12/ IL-23 and IL-17 inhibitors) do not impair vaccine immunogenicity. ${ }^{143154-56}$

A meta-analysis reported that rituximab-treated patients had a pooled OR for non-seroconversion (inability to mount a twofold increase in antibody concentrations postvaccination) ranging from 4.91 (95\% CI: 2.32 to 10.40 ) to 13.06 (95\% CI: 2.39 to 71.34) depending on the pneumococcal serotype. ${ }^{11}$ The effect of MTX is less than that of rituximab; pooled ORs for nonseroconversion ranged from 2.0 (95\% CI: 1.06 to 3.77 ) to 5.41 (95\% CI: 2.09 to 13.98 ) depending on the serotype. ${ }^{11}$
Interpretation of data from abatacept studies is complicated by concomitant MTX and/or a lack of controls. In one uncontrolled study of patients on subcutaneous abatacept (most of whom were also on MTX) vaccinated with PPSV23, 34 (74\%)/46 patients developed protective antibody titres, consistent with expected response. ${ }^{25}$ However, another study of 17 patients on intravenous abatacept vaccinated with PCV7 (13 of whom were receiving concomitant MTX) found a lower likelihood of a greater than equal to twofold increase in postvaccination antibody titre compared with patients on tocilizumab or controls. ${ }^{45}$ Lastly, in a pneumococcal booster study, the booster 
strategy improved antibody response in 23 abatacept-treated patients (half of whom were on MTX); however the antibody response was lower than in healthy controls. ${ }^{46}$

JAK inhibitors appear to have a modest impact on the rate of satisfactory responses to pneumococcal vaccinations (defined as a greater than equal to twofold increase in antibody concentrations in $\geq 6$ serotypes), at least to PPSV23 where there is comparative data published. ${ }^{3053}$ A placebo-controlled study of patients with RA vaccinated after 4 weeks of tofacitinib or placebo found that those on tofacitinib were less likely to develop a satisfactory antibody response compared with placebo $(45.1 \%$ vs $68.4 \%$, $-23 \%$ difference $(95 \% \mathrm{CI}$ : $-36.6 \%$ to $-9.6 \%)$ ), particularly if they were also on MTX (31.6\%). ${ }^{30}$ Temporary interruption in tofacitinib for 1 week prevaccination and 1 week postvaccination modestly improved PPSV23 response when compared with continuous tofacitinib, but this did not reach significance $(84.6 \%$ vs $75.0 \%,-9.6 \%$ difference $(95 \% \mathrm{CI}:-24.0 \%$ to $4.7 \%)) .{ }^{30} \mathrm{~A}$ final uncontrolled study of 106 baricitinib-treated patients $(89 \%$ of whom were also on MTX) vaccinated with PCV13 found that approximately two-third of patients received a satisfactory antibody response ${ }^{53}$; these proportions were similar to another study evaluating PCV13 responses in healthy controls and patients with RA not using DMARDs. ${ }^{50}$

Low-dose glucocorticoids taken concomitantly with other DMARD therapy have not been found to impact pneumococcal vaccine responses, ${ }^{53} 5758$ while high-dose glucocorticoids may adversely impact pneumococcal vaccine immunogenicity. ${ }^{59}$ Among patients with inflammatory diseases vaccinated with the PPSV23, 57\% of non-responders were taking prednisone $>20 \mathrm{mg}$ /day compared with $22 \%$ of vaccine responders $(\mathrm{p}=0.07) .{ }^{59}$ In an uncontrolled baricitinib study where approximately $30 \%$ of participants were taking concomitant low-dose corticosteroids (mean dose: $6.2 \mathrm{mg} /$ day), PCV13 response rates were similar in those taking corticosteroids versus those not taking corticosteroids (71\% (95\% CI: $53.4 \%$ to $83.9 \%$ ) vs $67 \%$ (95\% CI: $55.2 \%$ to $76.5 \%)) .{ }^{53}$ Similarly, in a study of patients on MTX with or without infliximab, concomitant low-dose glucocorticoids (prednisone equivalent $<10 \mathrm{mg} /$ day) did not adversely impact vaccine response. ${ }^{58}$

\section{Recommendations}

The EULAR, ACR and CDC all recommend pneumococcal vaccinations for patients with rheumatic disease taking DMARD therapy. ${ }^{406061}$ Patients should receive a dose of PCV13 followed by a dose of PPSV23 at least 8 weeks later. A second PPSV23 vaccine should be given 5 years after the first one. PCV13 followed by a booster of PPSV23 improves pneumococcal antibody responses for patients on conventional synthetic DMARDs and partially improves responses for patients on abatacept but may not improve vaccine response for those on rituximab. ${ }^{46}$

Patients should be given their first dose of a pneumococcal vaccine ideally before starting DMARD therapy. Patients on rituximab should receive the required vaccine dose at least 2 weeks before their next dose of rituximab is due. Although extrapolating from influenza studies and observational data raises the idea that holding MTX at the time of vaccination could improve pneumococcal vaccine response, this idea has yet to be studied.

\section{HERPES ZOSTER VACCINATION Background}

There are two approved herpes zoster vaccines-the recombinant zoster vaccine (RZV) (Shingrix) and the live zoster vaccine
(ZVL) (Zostavax). In non-head-to-head studies in the general population, the RZV appears more effective such that the ZVL is no longer marketed in the USA, although it is still used in many parts of the world. ${ }^{62}$ Response to zoster vaccine is measured by a humoral varicella zoster virus IgG and/or cell-mediated varicella zoster virus-specific T-cell enumeration. Although both measures correlated with vaccine efficacy, cell-mediated responses correlate more strongly with the risk of future shingles. ${ }^{63}$

\section{Effect of DMARD therapy on vaccine efficacy}

Few studies have evaluated the immunogenicity of zoster vaccines in patients with rheumatic disease.

Hundred and twelve patients with RA on MTX were vaccinated with the ZVL and then randomised to start tofacitinib or placebo 2-3 weeks postvaccination. Patients in both groups had similar postvaccine responses. ${ }^{52}$ In this study, approximately $40 \%$ of patients treated with placebo and $47 \%$ of patients treated with tofacitinib were taking concomitant glucocorticoids (mean dose: 7.1 and $5.9 \mathrm{mg} /$ day prednisone or equivalent, respectively). ZVL vaccine responses were similar in those taking glucocorticoids and those not taking glucocorticoids. ${ }^{52}$ TNF inhibitor-treated patients vaccinated with the ZVL developed $30 \%$ increases in humoral and cell-mediated responses relative to a placebo vaccine, which are about half the response observed in initial pivotal trials among healthy subjects. ${ }^{64}$ Zoster vaccines have not been studied in patients with rheumatic disease on rituximab, however, among patients with haematologic malignancies on anti-CD20 therapies (alone or in combination with other chemotherapies), 4 doses of the RZV produced significant T-cell responses. ${ }^{65}$ Zoster vaccine immunogenicity data for patients currently taking JAK inhibitors, abatacept and other biologics have not been reported.

\section{Safety in patients with rheumatic diseases}

While the ZVL vaccine is contraindicated in immunocompromised patients, given the theoretical concern of potential local or disseminated vaccine-strain varicella with vaccination, available data suggest it is safer than initially thought. In the study of MTX and tofacitinib above, there was one case of cutaneous vaccine dissemination in a patient on MTX randomised to start tofacitinib, however, this patient lacked primary immunity to varicella (ie, they did not have chickenpox as a child) and were not a candidate for the live vaccine. ${ }^{52}$ Among 633 United States Medicare patients inadvertently vaccinated while on biologics, no cases of shingles occurred in the 6 weeks postvaccination. ${ }^{10} \mathrm{Six}$ hundred patients on TNF inhibitors (with or without MTX and prednisone) randomised 1:1 to receive the ZVL versus placebo and found no cases of varicella infection or zoster within the subsequent 42-day risk period of highest interest. ${ }^{64}$ These data suggest that the ZVL may be given safely to those using TNF inhibitors with/without MTX and/or prednisone if the RZV is not available.

The recombinant vaccine is not live and is likely safe in patients with rheumatic diseases, however, phase III clinical trials excluded patients on immunosuppressive therapy. There has been theoretical concern that the adjuvant in the RZV may cause a flare of underlying inflammatory disease. The first retrospective review of 403 patients with rheumatic disease vaccinated with the RZV found a 7\% incidence of disease flare within 12 weeks of receiving a vaccine dose; this incidence was considered to be similar to expected rates from clinical trials. ${ }^{66}$ However, a second retrospective review of 359 patients with rheumatic diseases found that $16 \%$ had a flare of their disease within 12 
weeks of receiving a vaccine dose. ${ }^{67}$ The differences in these results may be related to a difference in flare definition, however neither was prospective or controlled. A post-hoc analysis of clinical trials (NCT01165177 and NCT01165229) pooled data from nearly 2000 patients (approximately half received vaccine) with self-reported inflammatory disease who were not treated with DMARDs. This analysis found similar high rates of vaccine efficacy and no new safety concerns, however, it is likely that these self-reported individuals had either mild or no disease given their lack of DMARD therapy. ${ }^{68}$ Future prospective, controlled studies are necessary to adequately evaluate safety and efficacy of this vaccine in the rheumatology setting.

\section{Recommendations}

The CDC recommends the RZV for all patients aged 50 and above. ${ }^{12}$ The European Medicines Agency recently approved the RZV for adults over age 18 with immunocompromising conditions, ${ }^{69}$ however, very little data exist in this age group and guidelines are not yet available for the use of this vaccine in patients with rheumatic diseases. The ACR recommends use of the ZVL for patients with RA over age $50,{ }^{40}$ and EULAR recommends zoster vaccination in high-risk patients, ${ }^{41}$ however, neither of these guidelines address the newer RZV. Given that immunocompromised patients with rheumatic diseases are at increased risk of zoster, ${ }^{670}$ future guidelines may be expanded to recommend the RZV for high-risk patients at a younger age (eg, 18 and older).

\section{SARS-COV-2 VACCINATION Background}

A growing number of SARS-CoV-2 vaccines are in use worldwide, including mRNA, adenoviral vector, protein subunit and inactivated virus vaccines. ${ }^{71}$ We will focus our discussion on two mRNA vaccines and two adenoviral vector vaccines, which have been most widely studied in patients with rheumatic diseases. In phase III trials, the BNT162b2 (Pfizer/BioNTech) mRNA vaccine was $95 \%$ effective (95\% CI: $90.3 \%$ to $97.6 \%)^{72}$ and the mRNA01273 (Moderna) vaccine was 94.1\% effective (95\% CI: $89.3 \%$ to $96.8 \%)^{73}$ in preventing symptomatic COVID-19 infection following the second dose. Phase III trials found the Ad26. COV2.S (Janssen/Johnson \& Johnson) single-dose vaccine to be $66.9 \%$ effective (95\% CI: $59.0 \%$ to $73.4 \%)^{74}$ and the ChAdOx1 nCoV-19/AZD1222 (University of Oxford/AstraZeneca/Serum Institute of India) vaccine to be $70.4 \%$ effective (95\% CI: $54.8 \%$ to 80.6 ) following the second dose. ${ }^{75}$

SARS-CoV-2 vaccine immunogenicity can be measured by humoral IgG to spike protein (not nucleocapsid protein) or cellular T-cell reactivity via interferon (IFN)- $\gamma$ response to SARS-CoV-2 peptide. Antibody responses are reported as 'seroconversion' (newly positive antispike protein $\operatorname{IgG}$ ), or by postvaccination antibody titres. The role of T-cell responses to SARS-CoV-2 vaccines are not fully understood, however emerging evidence suggests that T-cell responses may confer protection $^{7677}$ even in the absence of humoral response. ${ }^{78} 79$ However, we do not yet know how immunogenicity cut-offs correlate with efficacy, whether reduced absolute titres may still be adequate titres, or whether immune responses wane over time, making SARS-CoV-2 immunogenicity studies difficult to fully interpret.

\section{Effect of DMARD therapy on SARS-CoV-2 vaccine efficacy}

Early data in this setting are largely consistent with that from other vaccine studies. Data suggest that rituximab, ${ }^{80-84}$ glucocorticoids, ${ }^{82}{ }^{84}$ MTX,${ }^{828485}$ abatacept,${ }^{84}$ mycophenolate mofetil $^{84}$ and JAK inhibitors ${ }^{82}$ impair SARS-CoV-2 vaccine responses in many patients. The mRNA vaccine mechanism and potential impact of DMARD therapy is described in figure 1.

The largest observational study to date evaluated the BNT162b2 (Pfizer/BioNTech) mRNA vaccine in 686 patients with rheumatic diseases. Compared with controls where $100 \%$ seroconverted to vaccination (ie, newly positive antispike $\operatorname{IgG}$ ), seroconversion rates were significantly lower for patients on rituximab $(39 \%$ seroconverted, $p<0.0001)$, mycophenolate mofetil $(64 \%$ seroconverted, $\mathrm{p}<0.0001)$, abatacept (71\% seroconverted, $\mathrm{p}<0.0001)$, JAK inhibitors $(90 \%$ seroconverted, $\mathrm{p}=0.02)$, MTX (92\% seroconverted, $\mathrm{p}=0.02)$ and glucocorticoids (mean dose: $6.7 \mathrm{mg} / \mathrm{day}, 77 \%$ seroconverted, $\mathrm{p}<0.0001$ ), while other DMARDs (leflunomide, hydroxychloroquine, TNF, IL-6 and IL-17-inhibitors) did not significantly impact seroconversion. ${ }^{84}$ A logistic regression further identified anti-CD20 therapy (adjusted OR: 0.13, p<0.001), glucocorticoids (adjusted OR: 0.48, $\mathrm{p}=0.02$ ), abatacept (adjusted OR: 0.14, p<0.001) and mycophenolate mofetil (adjusted OR: 0.1, $\mathrm{p}=0.0013$ ) as independent predictors of a poor vaccine response. ${ }^{84}$ Another prospective study of 133 patients with immune-mediated inflammatory diseases on various DMARD therapies and 53 controls vaccinated with mRNA vaccines found that rituximab significantly reduced mRNA vaccine immunogenicity, JAK inhibitors and MTX moderately reduced antibody titres, and other therapies (TNF, IL-12/IL-23 and integrin inhibitors) had a modest impact on antibody formation. ${ }^{82}$

Risk factors for a poor humoral response on rituximab include a shorter duration between rituximab dose and vaccine, and lack of B-cell reconstitution. ${ }^{81} 86$ Rituximab-treated patients vaccinated 6 months after their last rituximab dose had a seropositivity rate around $20 \%$, and those vaccinated 1 year after the last rituximab dose had rates around $50 \%{ }^{84}$ Despite a reduced humoral response, early data suggest that rituximab-treated patients may still mount a normal cellular vaccine response, such that the net impact on clinical protection is not clear. ${ }^{86}$

MTX appears to reduce some aspects of the SARS-CoV-2 vaccine response. ${ }^{82} 8485$ In a New York cohort of patients with immune-mediated inflammatory disease, $72 \%$ of MTXtreated patients had adequate humoral antibody titres (defined as IgG to spike protein $>5000$ units) compared with $92.3 \%$ of patients with rheumatic disease not on MTX and 96.1\% of healthy controls $(\mathrm{p}=0.023) .{ }^{85}$ Patients on MTX also had reduced activated CD8 + T-cell response but a preserved CD4 + T-cell response. ${ }^{85}$ In the Furer et al cohort of 176 MTXtreated patients, $84 \%$ of all MTX-treated patients and $92 \%$ of patients on MTX-monotherapy seroconverted, compared with $100 \%$ of controls $(\mathrm{p}<0.05){ }^{84}$

TNF inhibitors appear to reduce SARS-CoV-2 postvaccination titres, ${ }^{82} 8788$ but do not seem to substantially impact rates of seroconversion ${ }^{83} 848788$-although antibody cut-offs for seroprotection are not defined. Among 865 infliximabtreated patients with inflammatory bowel disease given a single vaccine dose of the BNT162b2 mRNA vaccine or the ChAdOx1 nCoV-19 adenoviral vaccine had lower antibody concentrations and seroconversion rates compared with those on vedolizumab. ${ }^{88}$ However, in the 27 patients who were studied after a second vaccine dose of the mRNA vaccine, there was no difference in the rate of seroconversion $(85 \%$ vs $86 \%, \mathrm{p}=0.68) .{ }^{88}$ Similarly, in the Furer et al cohort, 172 


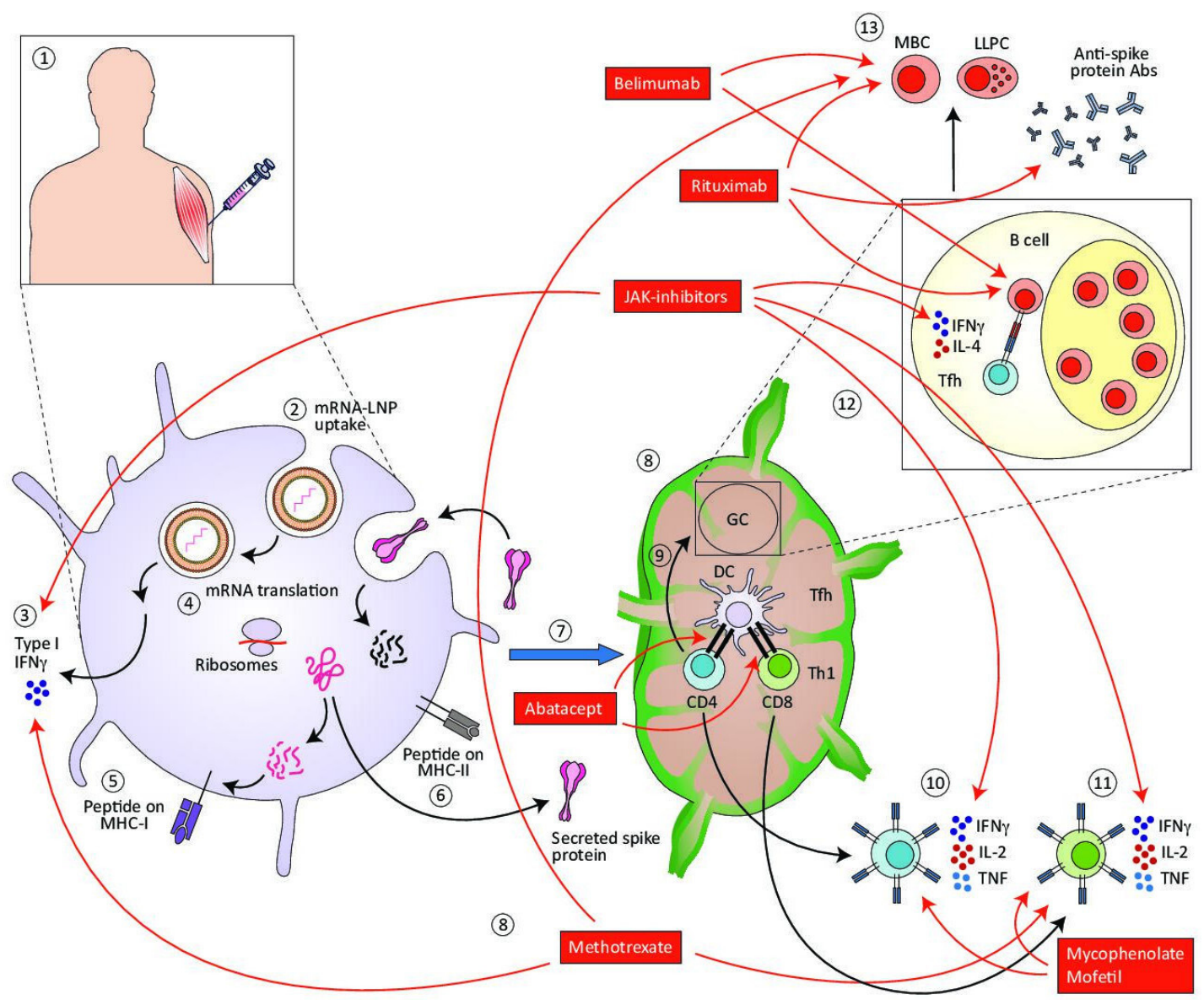

Figure 1 Mechanism of the mRNA SARS-CoV-2 vaccine and potential impact of DMARD therapy: (1) the mRNA vaccine is given as an intramuscular injection; (2) LPN coating the mRNA allow uptake into APCs ${ }^{135}$; (3) mRNA is recognised by Toll-like receptors/retinoic acid-inducible gene-I, triggering a type I IFN response; (4) mRNA is translated by ribosomes into peptides; (5) peptides are processed by the proteasome and presented on MHC-I or (6) post-translationally modified into secreted proteins, which can then be taken up by APCs and presented by MHC-II; (7) DCs are trafficked to lymph nodes where they (8) prime CD4 + and CD8+ T cells; (9) CD4 + T cells differentiate into Tfh cells, which form GC or (10) Th1 cells; (11) CD8 + T cells become circulating cytotoxic T cells; (12) in the GC, Tfh cells interact with B cells, resulting in (13) MBC and LLPCs secreting anti-spike protein Abs. ${ }^{135}{ }^{136}$ Low-dose MTX impacts expression of cytokines, ${ }_{1}^{137}$ B cell and CD8 + T-cell responses, with apparent preservation of CD4 + response. ${ }^{85}$ Mycophenolate mofetil reduces B and T lymphocyte proliferation. ${ }^{138}$ Abatacept is a soluble fusion CTLA-4 IgG, which prevents T-cell costimulation. ${ }^{139}$ JAK inhibitors reduce signalling by numerous cytokines, of particular importance in mRNA vaccines response are IFN- $\gamma_{1}$ IL-4 and IL-2 signalling. ${ }^{140}$ Rituximab depletes B cells by targeting CD20, which is expressed by early B cells but not mature plasma cells. ${ }^{141}$ Belimumab binds soluble BLyS, reducing B-cell survival. ${ }^{142}$ SARS-CoV-2 mRNA vaccine mechanism depictions are modified from figures attributed to Cagigi/Loré ${ }^{135}$ and Bettini/ Locci, ${ }^{136}$ licensed under CC by 4.0. Abs, antibodies; APCs, antigen-presenting cells; BLyS, B lymphocyte stimulator; CTLA, cytotoxic T-lymphocyteassociated protein 4; DCs, dendritic cells; GC, germinal centres; IL-4, interleukin-4; IFN, interferon; JAK, Janus kinase; LLPCs, long-lived plasma cells; LPN, lipid nanoparticle; MBC, memory B cells; MHC, major histocompatibility complex; MTX, methotrexate; Tfh, T follicular helper.

patients on TNF inhibitors fully vaccinated with BNT162b2 mRNA vaccine showed no significant difference in seroconversion rates compared with healthy controls. ${ }^{84}$ Whether reductions in quantitative humoral responses are of clinical significance is unknown.

JAK inhibitors likely reduce antibody titres and have a mild effect on seroconversion, although the clinical importance of these observations is unknown and data are scant. The 10 patients on JAK inhibitors in the Deepak et al cohort had a greater than sixfold reduction in titres compared with controls (95\% CI: 2.9 to $15.3, \mathrm{p}<0.05.)^{82}$ However, in the Furer et al study, among 21 patients on JAK inhibitor monotherapy and 24 on combination therapy, 19 (90\%) and 22 (92\%), respectively seroconverted, neither of which were significantly different from controls. ${ }^{84}$

\section{Safety in patients with rheumatic diseases}

Because of its substantial immunogenicity, there is concern that the SARS-CoV-2 vaccine may induce flares in patients with inflammatory diseases. This concern is supported by reports of thrombocytopaenic purpura ${ }^{89-92}$ and myocarditis/pericarditis $^{93-95}$ after vaccination. There have additionally been observational reports of new-onset immune-mediated disease ${ }^{96}$ and/ or disease flares after SARS-CoV-2 vaccination, ${ }^{96} 97$ which must be balanced against the risk of immune-mediated disease resulting from SARS-CoV-2 infection itself. ${ }^{98-100}$

The Furer et al cohort of rheumatic disease patients documented two fatalities postvaccination; one ANCA-vasculitis patient developed cutaneous vasculitis with subsequent fatal sepsis 3 weeks after the second vaccine dose and the second had a history of cardiovascular disease and died of a myocardial infarction 2 months after the second vaccine dose. Other 
adverse events of note were two cases of uveitis, one case of pericarditis, six cases of herpes zoster, and one case of herpes labialis, while risks of typical side effects were similar to the controls. ${ }^{84}$ Small prospective studies thus far have not found an increased in underlying inflammatory disease activity measures after SARS-CoV-2 vaccination, ${ }^{84} 87$ however, more prospective data are needed to understand the safety of these vaccines and risk of disease flare in patients with rheumatic diseases.

\section{Recommendations}

The ACR has provided detailed recommendations for management of DMARD therapy in the setting of the SARS-CoV-2 vaccine (table 2). ${ }^{101}$ EULAR is also developing guidelines for SARS-CoV-2 vaccines in patients with rheumatic diseases, which should be available in the near future. All patients with rheumatic diseases should receive the SARS-CoV-2 vaccine as per general population recommendations.

\section{HEPATITIS B VACCINATION Background}

There are three different single-antigen recombinant HBV vaccines available worldwide and several combination vaccines; however, the most common HBV vaccine is a yeast-derived singleantigen vaccine. $\mathrm{HBV}$ vaccine immunogenicity is measured by anti-HBV surface antibody, where a titre of $\geq 10 \mathrm{IU} / \mathrm{L}$ is considered to be seroprotective. ${ }^{102}$

\section{Effect of DMARD therapy on vaccine efficacy}

TNF and IL-12/IL-23 inhibitors have been found to reduce HBV vaccine immunogenicity, ${ }^{103-105}$ while most other medications have not been extensively evaluated.

TNF inhibitors reduce HBV vaccine immunogenicity, ${ }^{103-105}$ although there may be differences among TNF inhibitors, with the lower antibody response rates for infliximab and higher response rates for etanercept. ${ }^{105}$ Ustekinumab was evaluated in one study of 25 patients where vaccine responses were moderately reduced. ${ }^{105} \mathrm{~A}$ recent trial of a high-dose $\mathrm{HBV}$ vaccine in DMARD-treated patients resulted in higher antibody response rates (anti-HBs titre over $10 \mathrm{IU} / \mathrm{mL}$ ) when compared with a standard-dose vaccine, however this result did not reach significance $(61.1 \%$ vs $49.3 \%, \mathrm{p}>0.05) .{ }^{105}$

\section{Recommendations}

In the USA, HBV vaccination is recommended for adults at high risk (table 1). ${ }^{1261106-108}$ Ideally patients who require HBV vaccination should be vaccinated prior to starting DMARD therapy, particularly for high-risk patients starting rituximab. ${ }^{109}$

\section{HPV VACCINATION Background}

Three HPV vaccines are approved; however, the 9-valent vaccine is the only HPV vaccine currently available in the USA. Women with rheumatic diseases on immunosuppressive therapies are at increased risk of HPV and cervical cancer; this has been particularly well described in systemic lupus erythematosus (SLE) but is seen in other inflammatory diseases. ${ }^{110-115}$ HPV vaccine immunogenicity is measured by seroconversion to subtypes contained in the vaccine, although a minimum threshold for seroprotection is not defined.

\section{Effect of DMARD therapy on vaccine efficacy}

MTX and TNF inhibitors have been evaluated in patients with juvenile idiopathic arthritis, juvenile dermatomyositis, inflammatory bowel disease and SLE; in these patients, MTX and TNF inhibitors do not appear to impact postvaccination seroconversion rates. ${ }^{116-119}$ Patients with SLE on combination mycophenolate mofetil and low-dose glucocorticoids show moderately reduced seroconversion rates for HPV6 and HPV18, but not for other subtypes. ${ }^{118}$ Other DMARD therapies have not been evaluated in patients with rheumatic diseases.

\section{Recommendations}

The Center for Disease Control (CDC) recommends HPV vaccination for all patients (regardless of sex) at age 11 or 12 up through age $26 .{ }^{12}$ No specific changes in medications are recommended for the HPV vaccines. It is important to remember that HPV vaccines are given as a series and the treating rheumatologist should ensure that the entire series have been completed.

\section{TETANUS VACCINATION \\ Background}

The tetanus toxoid, reduced diphtheria toxoid and acellular pertussis (Tdap) vaccine is a single-dose vaccine. Tetanus toxoid is a T-cell-dependent antigen. Tetanus vaccine immunogenicity is typically measured by antitetanus toxoid $\operatorname{IgG}$ concentrations 4 weeks postvaccination, where an antibody concentration of $\geq 0.10 \mathrm{IU} / \mathrm{mL}$ is typically considered seroprotective, however, an endpoint of fourfold increase in antibody concentration is also sometimes used. ${ }^{120}$

\section{Effect of DMARD therapy on vaccine efficacy}

Rituximab reduces response to the tetanus vaccine, however, the degree of this reduction is inconsistent between studies. ${ }^{18} 121$ Studies of abatacept, ${ }^{122} 123$ JAK inhibitors ${ }^{53120}$ and TNF inhibitors $^{121} 124$ suggest a modest impairment in immunogenicity. IL- $6,{ }^{55}$ IL- $17^{55}$ and IL-12/IL-23 $3^{54}$ inhibitors have not been shown to impair tetanus vaccine immunogenicity.

Rituximab may have less of a profound impact on tetanus immunogenicity than other vaccines, possibly because most patients have previously had tetanus vaccine and may have residual tetanus-specific memory B cells. Patients with RA on rituximab + MTX and MTX monotherapy were able to mount similar rates of humoral response, defined as a greater than equal to fourfold rise in antitetanus IgG $(39.1 \%$ vs $42.3 \%, 95 \% \mathrm{CI}$ : -25.7 to 19.2$).{ }^{18}$ However, another study found that rituximab was associated with lower rates of protective antibodies titres $(\geq 0.1 \mathrm{IU} / \mathrm{mL})$ compared with other patients with inflammatory disease or controls (73\% vs 96\%-100\%) and only $9 \%$ of rituximab-treated patients had a greater than equal to fourfold rise in antibody titres. ${ }^{121}$

A study of patients with inflammatory bowel disease on TNF inhibitors found lower antibody titres relative to those on thiopurines or healthy controls $(\mathrm{p}<0.001)$, though average titres were still in the protective range. ${ }^{124}$ Other data have shown similar antibody response rates in TNF-treated patients relative to healthy controls. ${ }^{121}$ An uncontrolled study of subcutaneous abatacept found satisfactory tetanus vaccine response in 219 juvenile patients with idiopathic arthritis (regardless of MTX or concomitant glucocorticoids), ${ }^{122}$ while a smaller study of 20 adults vaccinated 2 weeks after a single dose of intravenous abatacept found approximately $10 \%$ lower rates of protective antibody development relative to controls. ${ }^{123}$ Delaying the tetanus vaccine to 8 weeks after abatacept improved response 
rates close to that of healthy controls. ${ }^{123}$ Studies of JAK inhibitors are uncontrolled, making it difficult to estimate the drug effect. However, relative to expected responses in the general population, baricitinib plus MTX-treated patients with RA show reduced antitetanus antibody concentrations, ${ }^{53}$ while tofacitinibtreated patients with psoriasis mount a seemingly satisfactory response. ${ }^{120}$ In a study of baricitinib and tetanus vaccination, concomitant glucocorticoids did not appear to have an adverse effect on rates of adequate humoral response; 52\% (95\% CI: $34.8 \%$ to $68 \%$ ) of those taking glucocorticoids versus 39\% (95\% CI: $28.9 \%$ to $51.1 \%$ ) of those not taking glucocorticoids. ${ }^{53}$

Studies of patients with psoriasis on ustekinumab ${ }^{54}$ and ixekizumab $^{55}$ did not find any change in postvaccination tetanus antibody response relative to untreated controls. Tocilizumab similarly does not appear to hamper antibody response to the tetanus vaccine. ${ }^{125}$

\section{Recommendations}

Adults and adolescents should receive a Tdap followed by boosters of tetanus and diphtheria toxoids (Td) every 10 years or when indicated due to a wound, although a booster may be either Td or Tdap. ${ }^{12}$ Tetanus vaccination should ideally be done prior to starting rituximab therapy.

\section{YF VACCINATION Background}

The YF vaccine is recommended to immunocompetent persons who live or travel to endemic areas. ${ }^{61}{ }^{126}$ However, this vaccine is live and is contraindicated in immunosuppressed patients including those receiving biologics and JAK inhibitors. ${ }^{41}$ YF vaccine immunogenicity is measured by postvaccination neutralising antibody titres.

\section{Effect of DMARD therapy on vaccine efficacy}

Because the YF vaccine is live, few studies have addressed the immunogenicity of this vaccine in patients with rheumatic diseases. A study from Brazil evaluated 31 patients who were inadvertently revaccinated (patients had primary immunity from a previous vaccine) while on biologics; these patients had lower, yet adequate antibody titres. ${ }^{127}$ Another 17 patients on infliximab + MTX achieved satisfactory antibody levels in all but one patient. ${ }^{128}$ Among 15 patients on MTX, all achieved seroprotection. ${ }^{129}$ Patients on corticosteroids (mean: $7 \mathrm{mg} /$ day, range: $5-20 \mathrm{mg} /$ day), 18/34 of whom were vaccine naive, also appeared to have satisfactory titres. ${ }^{130}$

\section{Safety in patients with rheumatic diseases}

Small studies suggest that the vaccine may be safer than previously thought for patients on MTX, ${ }^{127} 129131$ infliximab $^{127} 128$ and corticosteroids $<20 \mathrm{mg} /$ day. $^{130}$ A retrospective Swiss study of 92 patients on immunosuppressive medications (16 on MTX, 40 on corticosteroids, small numbers on other medications) who received the YF vaccine developed similar rates of side effects as healthy controls (controls had a similar proportion of patients with a primary YF vaccine history) and no serious adverse events. ${ }^{131}$ A prospective study of 15 patients on MTX ( $\leq 20 \mathrm{mg} /$ week) receiving a primary YF vaccine found slightly increased rates of YF RNA viraemia in MTX-treated patients relative to controls $(p>0.39)$, however these levels were never of clinical significance. ${ }^{129}$ In the study from Brazil above, 31 patients revaccinated on biologics had no adverse events. ${ }^{127}$

\section{Recommendations}

The YF vaccine should be avoided in patients who are immunosuppressed. In travels or patients in endemic areas at very high risk, patients and their providers may consider holding immunosuppressive therapy for vaccination. The typical requirement for doing this would be to hold for a sufficient time to allow for the medication to wash out and its biologic effect to dissipate depending on half-life, then vaccinate and then wait 2-4 weeks before resuming medication.

\section{CONCLUSION}

Vaccinations are critical in the care of patients with inflammatory diseases, especially for those on DMARD therapy, yet DMARD therapy can impair vaccine response. This issue is only becoming more important with the emergence of novel pathogens and resultant innovative vaccines. In this review, we have summarised the available data regarding DMARDs and vaccine responses. While the impact of DMARD therapy on vaccines is variable, there are consistent themes. Rituximab substantially reduces antibody response to vaccines, although T-cell responses may be preserved. MTX and abatacept reduce the immunogenicity of many vaccines. TNF and JAK inhibitors typically reduce absolute postvaccination antibody titres, though most patients (particularly those on TNF inhibitors) still achieve seroprotective levels. Other anticytokine therapies, including IL-6, IL-12/IL-23, and IL-17 inhibitors do not appear to have a measurable impact on vaccine immunogenicity.

Vaccine immunogenicity studies are limited by inconsistency in immunogenicity measures and heterogeneity of control groups. More data are needed for the SARS-CoV-2, HBV, HPV and zoster vaccines, and for less-common medications such as belimumab and newer anticytokine therapies. Lastly, few clinical trials have directly evaluated strategies to overcome this issue, such as timing vaccines around DMARD dosing, or utilising drug holidays. As our arsenal of DMARD therapy and vaccines grow, more clinical trials will be needed to assess the impact of DMARD therapy on vaccines, and to test strategies to optimise vaccine response.

Acknowledgements We wish to thank Claudia Bentley for design work of Figure 1.

Contributors MAF drafted the initial manuscript. All authors substantially contributed to the conception and design of the work, and the acquisition, analysis or interpretation of data for the work. All authors revised the manuscript for critically important intellectual content. All authors approve of the version to be published. All authors agree to be accountable for all aspects of the work in ensuring that questions related to the accuracy or integrity of any part of the work are appropriately investigated and resolved.

Funding MAF receives support from the NIH (KL2TR002370) and the Oregon Health \& Science University Department of Medicine Wheels Up program. JRC receives support from the $\mathrm{NIH}$ (P30AR072583). KLW receives support from BMS and Pfizer.

Competing interests MAF has received consulting fees for Revolo. JTR serves on ACIP HZ Workgroup, lead of ACR COVID Vaccine Guidance Task Force, member of ACR COVID-19 Vaccine Clinical Guideline Task Force, and is a member of EULAR Vaccine Guidance Task Force. JTR receives research grants and/or consulting for unrelated work: Amgen, Abbvie, BMS, CORRONA, Genentech, GSK, Lilly, Janssen, Novartis, Pfizer, UCB. KLW receives support from BMS and Pfizer. KLW has received consulting fees from Pfizer, AbbVie, Union Chimique Belge (UCB), Eli Lilly \& Company, Galapagos, GlaxoSmithKline (GSK), Roche, Gilead, BMS, Regeneron, Sanofi, AstraZeneca and Novartis.

Patient and public involvement Patients and/or the public were not involved in the design, or conduct, or reporting or dissemination plans of this research.

Patient consent for publication Not required.

Provenance and peer review Not commissioned; externally peer reviewed.

\section{ORCID iDs}

Marcia A Friedman http://orcid.org/0000-0001-6722-2159

Jeffrey R Curtis http://orcid.org/0000-0002-8907-8976 
Kevin L Winthrop http://orcid.org/0000-0002-3892-6947

\section{REFERENCES}

1 Furer V, Rondaan C, Heijstek M, et al. Incidence and prevalence of vaccine preventable infections in adult patients with autoimmune inflammatory rheumatic diseases (AlIRD): a systemic literature review Informing the 2019 update of the EULAR recommendations for vaccination in adult patients with AIIRD. RMD Open 2019;5:e001041.

2 Wolfe F, Mitchell DM, Sibley JT, et al. The mortality of rheumatoid arthritis. Arthritis Rheum 1994;37:481-94.

3 Glück T, Müller-Ladner U. Vaccination in patients with chronic rheumatic or autoimmune diseases. Clin Infect Dis 2008;46:1459-65.

4 Crowson CS, Hoganson DD, Fitz-Gibbon PD, et al. Development and validation of a risk score for serious infection in patients with rheumatoid arthritis. Arthritis Rheum 2012;64:2847-55.

5 Doran MF, Crowson CS, Pond GR, et al. Predictors of infection in rheumatoid arthritis. Arthritis Rheum 2002;46:2294-300.

6 Yun $\mathrm{H}$, Xie F, Delzell E, et al. Risks of herpes zoster in patients with rheumatoid arthritis according to biologic disease-modifying therapy. Arthritis Care Res 2015;67:731-6.

7 Nakafero G, Grainge MJ, Myles PR, et al. Effectiveness of inactivated influenza vaccine in autoimmune rheumatic diseases treated with disease-modifying antirheumatic drugs. Rheumatology 2020;59:3666-75.

8 Zhang J, Delzell E, Xie F, et al. The use, safety, and effectiveness of herpes zoster vaccination in individuals with inflammatory and autoimmune diseases: a longitudinal observational study. Arthritis Res Ther 2011;13:R174.

9 Hmamouchi I, Winthrop K, Launay 0, et al. Low rate of influenza and pneumococcal vaccine coverage in rheumatoid arthritis: data from the International COMORA cohort. Vaccine 2015;33:1446-52.

10 Zhang J, Xie F, Delzell E, et al. Association between vaccination for herpes zoster and risk of herpes zoster infection among older patients with selected immune-mediated diseases. JAMA 2012;308:43-9.

11 van Aalst M, Langedijk AC, Spijker R, et al. The effect of immunosuppressive agents on immunogenicity of pneumococcal vaccination: a systematic review and metaanalysis. Vaccine 2018;36:5832-45.

12 Freedman MS, Ault K, Bernstein H. Advisory Committee on Immunization Practices Recommended Immunization Schedule for Adults Aged 19 Years or Older - United States, 2021. MMWR Morb Mortal Wkly Rep 2021;70:193-6.

13 Grohskopf LA, Alyanak E, Broder KR, et al. Prevention and Control of Seasonal Influenza with Vaccines: Recommendations of the Advisory Committee on Immunization Practices - United States, 2020-21 Influenza Season. MMWR Recomm Rep 2020;69:1-24.

14 Hua C, Barnetche T, Combe B, et al. Effect of methotrexate, anti-tumor necrosis factor $\alpha$, and rituximab on the immune response to influenza and pneumococcal vaccines in patients with rheumatoid arthritis: a systematic review and metaanalysis. Arthritis Care Res 2014;66:1016-26.

15 Oren S, Mandelboim M, Braun-Moscovici Y, et al. Vaccination against influenza in patients with rheumatoid arthritis: the effect of rituximab on the humoral response. Ann Rheum Dis 2008;67:937-41.

16 Rehnberg M, Brisslert M, Amu S, et al. Vaccination response to protein and carbohydrate antigens in patients with rheumatoid arthritis after rituximab treatment. Arthritis Res Ther 2010;12:R111.

17 Arad U, Tzadok S, Amir S, et al. The cellular immune response to influenza vaccination is preserved in rheumatoid arthritis patients treated with rituximab. Vaccine 2011;29:1643-8.

18 Bingham CO, Looney RJ, Deodhar A, et al. Immunization responses in rheumatoid arthritis patients treated with rituximab: results from a controlled clinical trial. Arthritis Rheum 2010:62:64-74.

19 Lakota K, Perdan-Pirkmajer K, Sodin-Šemrl S, et al. The immunogenicity of seasonal and pandemic influenza vaccination in autoimmune inflammatory rheumatic patients-a 6-month follow-up prospective study. Clin Rheumatol 2019;38:1277-92.

20 Richi P, Martín MD, Navío MT, et al. Antibody responses to influenza vaccine in patients on biological therapy: results of RIER cohort study. Med Clin 2019:153:380-6.

21 van Assen S, Holvast A, Benne CA, et al. Humoral responses after influenza vaccination are severely reduced in patients with rheumatoid arthritis treated with rituximab. Arthritis Rheum 2010;62:75-81.

22 Park JK, Lee MA, Lee EY, et al. Effect of methotrexate discontinuation on efficacy of seasonal influenza vaccination in patients with rheumatoid arthritis: a randomised clinical trial. Ann Rheum Dis 2017;76:1559-65.

23 Park JK, Lee YJ, Shin K, et al. Impact of temporary methotrexate discontinuation for 2 weeks on immunogenicity of seasonal influenza vaccination in patients with rheumatoid arthritis: a randomised clinical trial. Ann Rheum Dis 2018;77:898-904.

24 Adler S, Krivine A, Weix J, et al. Protective effect of A/H1N1 vaccination in immunemediated disease--a prospectively controlled vaccination study. Rheumatology 2012;51:695-700.
25 Alten R, Bingham CO, Cohen SB, et al. Antibody response to pneumococcal and influenza vaccination in patients with rheumatoid arthritis receiving abatacept. $B M C$ Musculoskelet Disord 2016;17:231.

26 Ribeiro AC, Laurindo IM, Guedes LK, et al. Abatacept and reduced immune response to pandemic 2009 influenza A/H1N1 vaccination in patients with rheumatoid arthritis. Arthritis Care Res 2013:65:476-80.

27 Fomin I, Caspi D, Levy V, et al. Vaccination against influenza in rheumatoid arthritis: the effect of disease modifying drugs, including TNF alpha blockers. Ann Rheum Dis 2006;65:191-4

28 Gelinck LBS, van der Bij AE, Beyer WEP, et al. The effect of anti-tumour necrosis factor alpha treatment on the antibody response to influenza vaccination. Ann Rheum Dis 2008;67:713-6.

29 França ILA, Ribeiro ACM, Aikawa NE, et al. TNF blockers show distinct patterns of immune response to the pandemic influenza A H1N1 vaccine in inflammatory arthritis patients. Rheumatology 2012;51:2091-8.

30 Winthrop KL, Silverfield J, Racewicz A, et al. The effect of tofacitinib on pneumococcal and influenza vaccine responses in rheumatoid arthritis. Ann Rheum Dis 2016;75:687-95.

31 Tsuru T, Terao K, Murakami M, et al. Immune response to influenza vaccine and pneumococcal polysaccharide vaccine under IL-6 signal inhibition therapy with tocilizumab. Mod Rheumatol 2014:24:511-6.

32 Doornekamp L, Goetgebuer RL, Schmitz KS, et al. High Immunogenicity to Influenza Vaccination in Crohn's Disease Patients Treated with Ustekinumab. Vaccines 2020;8:455.

33 Chioato A, Noseda E, Stevens M, et al. Treatment with the interleukin-17A-blocking antibody secukinumab does not interfere with the efficacy of influenza and meningococcal vaccinations in healthy subjects: results of an open-label, parallelgroup, randomized single-center study. Clin Vaccine Immunol 2012;19:1597-602.

34 Furer V, Zisman D, Kaufman I, et al. Immunogenicity and safety of vaccination against seasonal influenza vaccine in patients with psoriatic arthritis treated with secukinumab. Vaccine 2020;38:847-51.

35 Richi P, Martín MD, de Ory F, et al. Secukinumab does not impair the immunogenic response to the influenza vaccine in patients. RMD Open 2019;5:e001018.

36 Park JK, Lee YJ, Bitoun S, et al. Interaction between B-cell activation factor and methotrexate impacts immunogenicity of seasonal influenza vaccination in patients with rheumatoid arthritis. Ann Rheum Dis 2019;78:282-4.

37 Pépin S, Donazzolo Y, Jambrecina A, et al. Safety and immunogenicity of a quadrivalent inactivated influenza vaccine in adults. Vaccine 2013;31:5572-8.

38 Elkayam O, Bashkin A, Mandelboim M, et al. The effect of infliximab and timing of vaccination on the humoral response to influenza vaccination in patients with rheumatoid arthritis and ankylosing spondylitis. Semin Arthritis Rheum 2010;39:442-7.

39 Fiore AE, Uyeki TM, Broder K, et al. Prevention and control of influenza with vaccines: recommendations of the Advisory Committee on immunization practices (ACIP), 2010. MMWR Recomm Rep 2010;59:1-62.

40 Singh JA, Saag KG, Bridges SL, et al. 2015 American College of rheumatology guideline for the treatment of rheumatoid arthritis. Arthritis Rheumatol 2016:68:1-26.

41 Furer V, Rondaan C, Heijstek MW, et al. 2019 update of EULAR recommendations for vaccination in adult patients with autoimmune inflammatory rheumatic diseases. Ann Rheum Dis 2020;79:39-52.

42 Colmegna I, Useche ML, Rodriguez K, et al. Immunogenicity and safety of highdose versus standard-dose inactivated influenza vaccine in rheumatoid arthritis patients: a randomised, double-blind, active-comparator trial. Lancet Rheumatol 2020:2:e14-23.

43 Stapleton JT, Wagner N, Tuetken R, et al. High dose trivalent influenza vaccine compared to standard dose vaccine in patients with rheumatoid arthritis receiving TNF-alpha inhibitor therapy and healthy controls: results of the DMID 10-0076 randomized clinical trial. Vaccine 2020:38:3934-41.

44 Caldera F, Hillman L, Saha S, et al. Immunogenicity of high dose influenza vaccine for patients with inflammatory bowel disease on anti-TNF monotherapy: a randomized clinical trial. Inflamm Bowel Dis 2020;26:593-602.

45 Crnkic Kapetanovic M, Saxne T, Jönsson G, et al. Rituximab and abatacept but not tocilizumab impair antibody response to pneumococcal conjugate vaccine in patients with rheumatoid arthritis. Arthritis Res Ther 2013;15:R171.

46 Nived $P$, Jönsson $G$, Settergren B, et al. Prime-boost vaccination strategy enhances immunogenicity compared to single pneumococcal conjugate vaccination in patients receiving conventional DMARDs, to some extent in abatacept but not in rituximabtreated patients. Arthritis Res Ther 2020;22:36.

47 Ben Nessib D, Fazaa A, Miladi S, et al. Do immunosuppressive agents hamper the vaccination response in patients with rheumatic diseases? A review of the literature. Therapie 2021;76:215-9.

48 Kapetanovic MC, Roseman C, Jönsson G, et al. Antibody response is reduced following vaccination with 7 -valent conjugate pneumococcal vaccine in adult methotrexate-treated patients with established arthritis, but not those treated with tumor necrosis factor inhibitors. Arthritis Rheum 2011;63:3723-32.

49 Kapetanovic MC, Nagel J, Nordström I, et al. Methotrexate reduces vaccine-specific immunoglobulin levels but not numbers of circulating antibody-producing B cells 
in rheumatoid arthritis after vaccination with a conjugate pneumococcal vaccine. Vaccine 2017:35:903-8.

50 Nived P, Saxne T, Geborek P, et al. Antibody response to 13-valent pneumococcal conjugate vaccine is not impaired in patients with rheumatoid arthritis or primary Sjögren's syndrome without disease modifying treatment. BMC Rheumatol 2018:2:12.

51 Rasmussen SL, Fuursted K, Nielsen KA, et al. Pneumococcal antibody protection in patients with autoimmune inflammatory rheumatic diseases with varying vaccination status. Scand I Rheumatol 2020;49:353-60.

52 Winthrop KL, Wouters AG, Choy EH, et al. The safety and immunogenicity of live zoster vaccination in patients with rheumatoid arthritis before starting tofacitinib: a randomized phase II trial. Arthritis Rheumatol 2017:69:1969-77.

53 Winthrop KL, Bingham CO, Komocsar WJ, et al. Evaluation of pneumococcal and tetanus vaccine responses in patients with rheumatoid arthritis receiving baricitinib: results from a long-term extension trial substudy. Arthritis Res Ther 2019;21:102.

54 Brodmerkel C, Wadman E, Langley RG, et al. Immune response to pneumococcus and tetanus toxoid in patients with moderate-to-severe psoriasis following long-term ustekinumab use. J Drugs Dermatol 2013;12:1122-9.

55 Gomez EV, Bishop JL, Jackson K, et al. Response to tetanus and pneumococcal vaccination following administration of ixekizumab in healthy participants. BioDrugs 2017;31:545-54.

56 Kapetanovic MC, Saxne T, Sjöholm A, et al. Influence of methotrexate, TNF blockers and prednisolone on antibody responses to pneumococcal polysaccharide vaccine in patients with rheumatoid arthritis. Rheumatology 2006;45:106-11.

57 Richi P, Yuste J, Navio T, et al. Impact of biological therapies on the immune response after pneumococcal vaccination in patients with autoimmune inflammatory diseases. Vaccines 2021;9:203.

58 Visvanathan S, Keenan GF, Baker DG, et al. Response to pneumococcal vaccine in patients with early rheumatoid arthritis receiving infliximab plus methotrexate or methotrexate alone. J Rheumatol 2007:34:952-7.

59 Fischer L, Gerstel PF, Poncet A, et al. Pneumococcal polysaccharide vaccination in adults undergoing immunosuppressive treatment for inflammatory diseases--a longitudinal study. Arthritis Res Ther 2015;17:151.

60 van Assen S, Agmon-Levin N, Elkayam 0, et al. EULAR recommendations for vaccination in adult patients with autoimmune inflammatory rheumatic diseases. Ann Rheum Dis 2011;70:414-22.

61 Freedman M, Kroger A, Hunter P, et al. Recommended adult immunization schedule, United States, 2020. Ann Intern Med 2020;172:337-47.

62 Lal H, Cunningham AL, Godeaux 0, et al. Efficacy of an adjuvanted herpes zoster subunit vaccine in older adults. N Eng/ J Med 2015;372:2087-96.

63 Cunningham AL, Heineman TC, Lal H, et al. Immune responses to a recombinant glycoprotein $\mathrm{E}$ herpes zoster vaccine in adults aged 50 years or older. I Infect Dis 2018;217:1750-60

64 Curtis JBS, Cofield S, Bassler J. Results from a randomized controlled trial of the safety of the live varicella vaccine in TNF-treated patients [abstract]. Arthritis Rheumatol 2019;71.

65 Parrino J, McNeil SA, Lawrence SJ, et al. Safety and immunogenicity of inactivated varicella-zoster virus vaccine in adults with hematologic malignancies receiving treatment with anti-CD20 monoclonal antibodies. Vaccine 2017:35:1764-9.

66 Stevens E, Weinblatt ME, Massarotti E, et al. Safety of the zoster vaccine recombinant adjuvanted in rheumatoid arthritis and other systemic rheumatic disease patients: a single center's experience with 400 patients. ACR Open Rheumatol 2020;2:357-61.

67 Lenfant T, Jin Y, Kirchner E, et al. Safety of recombinant zoster vaccine: a retrospective study of 622 rheumatology patients. Rheumatology 2021. doi:10.1093/rheumatology/keab139. [Epub ahead of print: 09 Feb 2021].

68 Dagnew AF, Rausch D, Hervé C, et al. Efficacy and serious adverse events profile of the adjuvanted recombinant zoster vaccine in adults with pre-existing potential immune-mediated diseases: a pooled post hoc analysis on two parallel randomized trials. Rheumatology 2021;60:1226-33.

69 Agency EM. Shingrix 2020, 2021. Available: https://www.ema.europa.eu/en/ medicines/human/EPAR/shingrix [Accessed 29 Jun 2021].

70 Insinga RP, Itzler RF, Pellissier JM, et al. The incidence of herpes zoster in a United States administrative database. J Gen Intern Med 2005;20:748-53.

71 Creech CB, Walker SC, Samuels RJ. SARS-CoV-2 vaccines. JAMA 2021;325:1318-20.

72 Polack FP, Thomas SJ, Kitchin N, et al. Safety and efficacy of the BNT162b2 mRNA Covid-19 vaccine. N Engl J Med 2020;383:2603-15.

73 Baden LR, El Sahly HM, Essink B, et al. Efficacy and safety of the mRNA-1273 SARSCoV-2 vaccine. N Eng/ J Med 2021;384:403-16.

74 Sadoff J, Gray G, Vandebosch A, et al. Safety and efficacy of single-dose Ad26. COV2.S vaccine against Covid-19. N Engl J Med 2021;384:2187-201.

75 Voysey M, Clemens SAC, Madhi SA, et al. Safety and efficacy of the ChAdOx $1 \mathrm{nCoV}$ 19 vaccine (AZD1222) against SARS-CoV-2: an interim analysis of four randomised controlled trials in Brazil, South Africa, and the UK. Lancet 2021;397:99-111.

76 Sattler A, Angermair S, Stockmann H, et al. SARS-CoV-2-specific T cell responses and correlations with COVID-19 patient predisposition. J Clin Invest 2020;130:6477-89.
77 Tan AT, Linster M, Tan CW, et al. Early induction of functional SARS-CoV-2-specific T cells associates with rapid viral clearance and mild disease in COVID-19 patients. Cell Rep 2021;34:108728.

78 Schwarzkopf S, Krawczyk A, Knop D, et al. Cellular immunity in COVID-19 Convalescents with PCR-confirmed infection but with undetectable SARS-CoV-2Specific IgG. Emerg Infect Dis 2021;27:122-9.

79 Wang Z, Yang X, Zhong J, et al. Exposure to SARS-CoV-2 generates T-cell memory in the absence of a detectable viral infection. Nat Commun 2021;12:1724.

80 Etemadifar M, Sigari AA, Sedaghat N, et al. Acute relapse and poor immunization following COVID-19 vaccination in a rituximab-treated multiple sclerosis patient. Hum Vaccin Immunother 2021:1-3.

81 Spiera R, Jinich S, Jannat-Khah D. Rituximab, but not other antirheumatic therapies, is associated with impaired serological response to SARS- CoV-2 vaccination in patients with rheumatic diseases. Ann Rheum Dis 2021. doi:10.1136/ annrheumdis-2021-220604. [Epub ahead of print: 11 May 2021].

82 Deepak P, Kim W, Paley MA, et al. Glucocorticoids and B cell depleting agents substantially impair immunogenicity of mRNA vaccines to SARS-CoV-2. medRxiv 2021. doi:10.1101/2021.04.05.21254656. [Epub ahead of print: 09 Apr 2021].

83 Boyarsky BJ, Ruddy JA, Connolly CM, et al. Antibody response to a single dose of SARS-CoV-2 mRNA vaccine in patients with rheumatic and musculoskeletal diseases. Ann Rheum Dis 2021:annrheumdis-2021-220289.

84 Furer V, Eviatar T, Zisman D, et al. Immunogenicity and safety of the BNT162b2 mRNA COVID-19 vaccine in adult patients with autoimmune inflammatory rheumatic diseases and in the general population: a multicentre study. Ann Rheum Dis 2021:199-201.

85 Haberman RH, Herati R, Simon D, et al. Methotrexate hampers immunogenicity to BNT162b2 mRNA COVID-19 vaccine in immune-mediated inflammatory disease. Ann Rheum Dis 2021. doi:10.1136/annrheumdis-2021-220597. [Epub ahead of print: 25 May 2021].

86 Bonelli MM, Mrak D, Perkmann T, et al. SARS-CoV-2 vaccination in rituximab-treated patients: evidence for impaired humoral but inducible cellular immune response. Ann Rheum Dis 2021. doi:10.1136/annrheumdis-2021-220408. [Epub ahead of print: 06 May 2021].

87 Geisen UM, Berner DK, Tran F, et al. Immunogenicity and safety of anti-SARSCoV-2 mRNA vaccines in patients with chronic inflammatory conditions and immunosuppressive therapy in a monocentric cohort. Ann Rheum Dis 2021. doi:10.1136/annrheumdis-2021-220272. [Epub ahead of print: 24 Mar 2021].

88 Kennedy NA, Lin S, Goodhand JR, et al. Infliximab is associated with attenuated immunogenicity to BNT162b2 and ChAdOx1 nCoV-19 SARS-CoV-2 vaccines in patients with IBD. Gut 2021. doi:10.1136/gutjnl-2021-324789. [Epub ahead of print: 26 Apr 2021].

89 Greinacher A, Thiele T, Warkentin TE, et al. Thrombotic thrombocytopenia after ChAdOx1 nCov-19 vaccination. N Engl I Med 2021;384:2092-101.

90 Schultz NH, Sørvoll IH, Michelsen AE, et al. Thrombosis and thrombocytopenia after ChAdOx1 nCoV-19 vaccination. N Engl J Med 2021;384:2124-30

91 Lee E-J, Cines DB, Gernsheimer T, et al. Thrombocytopenia following pfizer and Moderna SARS-CoV-2 vaccination. Am J Hematol 2021;96:534-7.

92 Welsh KJ, Baumblatt J, Chege W, et al. Thrombocytopenia including immune thrombocytopenia after receipt of mRNA COVID-19 vaccines reported to the vaccine adverse event reporting system (VAERS). Vaccine 2021;39:3329-32.

93 Gargano JW, Wallace M, Hadler SC, et al. Use of mRNA COVID-19 Vaccine After Reports of Myocarditis Among Vaccine Recipients: Update from the Advisory Committee on Immunization Practices - United States, June 2021. MMWR Morb Mortal Wkly Rep 2021;70:977-82.

94 Montgomery J, Ryan M, Engler R, et al. Myocarditis following immunization with mRNA COVID-19 vaccines in members of the US military. JAMA Cardiol 2021. doi:10.1001/jamacardio.2021.2833. [Epub ahead of print: 29 Jun 2021].

95 Kim HW, Jenista ER, Wendell DC. Patients with acute myocarditis following mRNA COVID-19 vaccination. JAMA Cardiol 2021:e212828.

96 Watad A, De Marco G, Mahajna H, et al. Immune-Mediated disease flares or new-onset disease in 27 subjects following mRNA/DNA SARS-CoV-2 vaccination. Vaccines 2021;9:435.

97 Munguía-Calzada P, Drake-Monfort M, Armesto S, et al. Psoriasis flare after influenza vaccination in Covid-19 era: a report of four cases from a single center. Dermatol Ther 2021;34:e14684.

98 Chang SE, Feng A, Meng W, et al. New-Onset IgG autoantibodies in hospitalized patients with COVID-19. medRxiv 2021. doi:10.1101/2021.01.27.21250559. [Epub ahead of print: 29 Jan 2021].

99 Liu Y, Sawalha AH, Lu Q. COVID-19 and autoimmune diseases. Curr Opin Rheumatol 2021;33:155-62.

100 Galeotti C, Bayry J. Autoimmune and inflammatory diseases following COVID-19. Nat Rev Rheumatol 2020;16:413-4.

101 Curtis JR, Johnson SR, Anthony DD, et al. American College of rheumatology guidance for COVID-19 vaccination in patients with rheumatic and musculoskeletal diseases: version 1. Arthritis Rheumatol 2021;73:1093-107.

102 Kwon SY, Lee CH. Epidemiology and prevention of hepatitis B virus infection. Korean J Hepatol 2011;17:87-95. 
103 Gisbert JP, Villagrasa JR, Rodríguez-Nogueiras A, et al. Efficacy of hepatitis B vaccination and revaccination and factors impacting on response in patients with inflammatory bowel disease. Am J Gastroenterol 2012;107:1460-6.

104 Salinas GF, De Rycke L, Barendregt B, et al. Anti-TNF treatment blocks the induction of T cell-dependent humoral responses. Ann Rheum Dis 2013;72:1037-43.

105 Haykir Solay A, Eser F. High dose hepatitis B vaccine is not effective in patients using immunomodulatory drugs: a pilot study. Hum Vaccin Immunother 2019;15:1177-82.

106 Abara WE, Qaseem A, Schillie S, et al. Hepatitis B vaccination, screening, and linkage to care: best practice advice from the American College of physicians and the centers for disease control and prevention. Ann Intern Med 2017; 167:794-804.

107 Terrault NA, Lok ASF, McMahon BJ, et al. Update on prevention, diagnosis, and treatment of chronic hepatitis B: AASLD 2018 hepatitis B guidance. Hepatology 2018:67:1560-99.

108 Schillie S, Vellozzi C, Reingold A, et al. Prevention of hepatitis B virus infection in the United States: recommendations of the Advisory Committee on immunization practices. MMWR Recomm Rep 2018;67:1-31.

109 Myint A, Tong MJ, Beaven SW. Reactivation of hepatitis B virus: a review of clinical guidelines. Clin Liver Dis 2020;15:162-7.

110 Kim SC, Glynn RJ, Giovannucci E, et al. Risk of high-grade cervical dysplasia and cervical cancer in women with systemic inflammatory diseases: a population-based cohort study. Ann Rheum Dis 2015;74:1360-7.

111 Zard E, Arnaud L, Mathian A, et al. Increased risk of high grade cervical squamous intraepithelial lesions in systemic lupus erythematosus: a meta-analysis of the literature. Autoimmun Rev 2014;13:730-5.

112 Dreyer L, Faurschou M, Mogensen M, et al. High incidence of potentially virusinduced malignancies in systemic lupus erythematosus: a long-term followup study in a Danish cohort. Arthritis Rheum 2011:63:3032-7.

113 Santana IU, Gomes AdoN, Lyrio Leomar D'Cirqueira, et al. Systemic lupus erythematosus, human papillomavirus infection, cervical pre-malignant and malignant lesions: a systematic review. Clin Rheumatol 2011;30:665-72.

114 Feldman CH, Kim SC. Should we target patients with autoimmune diseases for human papillomavirus vaccine uptake? Expert Rev Vaccines 2014;13:931-4.

115 Kane S, Khatibi B, Reddy D. Higher incidence of abnormal Pap smears in women with inflammatory bowel disease. Am I Gastroenterol 2008;103:631-6.

116 Pellegrino P, Radice S, Clementi E. Immunogenicity and safety of the human papillomavirus vaccine in patients with autoimmune diseases: a systematic review. Vaccine 2015;33:3444-9.

117 Heijstek MW, Scherpenisse M, Groot N, et al. Immunogenicity and safety of the bivalent HPV vaccine in female patients with juvenile idiopathic arthritis: a prospective controlled observational cohort study. Ann Rheum Dis 2014;73:1500-7.

118 Mok CC, Ho LY, Fong LS, et al. Immunogenicity and safety of a quadrivalent human papillomavirus vaccine in patients with systemic lupus erythematosus: a case-control study. Ann Rheum Dis 2013;72:659-64.

119 Rotstein Grein IH, Pinto NF, Lobo A, et al. Safety and immunogenicity of the quadrivalent human papillomavirus vaccine in patients with childhood systemic lupus erythematosus: a real-world interventional multi-centre study. Lupus 2020;29:934-42.

120 Winthrop KL, Korman N, Abramovits W, et al. T-cell-mediated immune response to pneumococcal conjugate vaccine (PCV-13) and tetanus toxoid vaccine in patients with moderate-to-severe psoriasis during tofacitinib treatment. J Am Acad Dermatol 2018;78:1149-55.

121 Bühler S, Jaeger VK, Adler S, et al. Safety and immunogenicity of tetanus/diphtheria vaccination in patients with rheumatic diseases-a prospective multi-centre cohort study. Rheumatology 2019;58:1585-96.
122 Brunner HI, Tzaribachev N, Cornejo GV, et al. Maintenance of antibody response to diphtheria/tetanus vaccine in patients aged 2-5years with polyarticular-course juvenile idiopathic arthritis receiving subcutaneous abatacept. Pediatr Rheumatol Online J 2020;18:19.

123 Tay L, Leon F, Vratsanos G, et al. Vaccination response to tetanus toxoid and 23-valent pneumococcal vaccines following administration of a single dose of abatacept: a randomized, open-label, parallel group study in healthy subjects. Arthritis Res Ther 2007:9:R38.

124 Caldera F, Saha S, Wald A, et al. Lower sustained diphtheria and pertussis antibody concentrations in inflammatory bowel disease patients. Dig Dis Sci 2018:63:1532-40.

125 Bingham CO, Rizzo W, Kivitz A, et al. Humoral immune response to vaccines in patients with rheumatoid arthritis treated with tocilizumab: results of a randomised controlled trial (VISARA). Ann Rheum Dis 2015;74:818-22.

126 Staples JE, Gershman M, Fischer M. Yellow fever vaccine: recommendations of the Advisory Committee on immunization practices (ACIP). MMWR Recomm Rep 2010;59:1-27.

127 Oliveira ACV, Mota LMH, Santos-Neto LL, et al. Seroconversion in patients with rheumatic diseases treated with immunomodulators or immunosuppressants, who were inadvertently revaccinated against yellow fever. Arthritis Rheumatol 2015;67:582-3

128 Scheinberg M, Guedes-Barbosa LS, Mangueira C, et al. Yellow fever revaccination during infliximab therapy. Arthritis Care Res 2010;62:896-8.

129 Bühler S, Jaeger VK, Eperon G, et al. Safety and immunogenicity of a primary yellow fever vaccination under low-dose methotrexate therapy-a prospective multi-centre pilot study1. J Travel Med 2020;27:taaa126.

130 Kernéis S, Launay O, Ancelle T, et al. Safety and immunogenicity of yellow fever 17D vaccine in adults receiving systemic corticosteroid therapy: an observational cohort study. Arthritis Care Res 2013;65:1522-8.

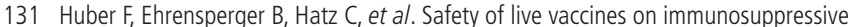
or immunomodulatory therapy —a retrospective study in three Swiss travel clinics. J Travel Med 2018;25.

132 Jacobson DL, Bousvaros A, Ashworth L, et al. Immunogenicity and tolerability to human papillomavirus-like particle vaccine in girls and young women with inflammatory bowel disease. Inflamm Bowel Dis 2013;19:1441-9.

133 Grein IHR, Pinto NBF, Groot N, et al. Safety and immunogenicity of the quadrivalent human papillomavirus vaccine in patients with juvenile dermatomyositis: a realworld multicentre study. Pediatr Rheumatol Online J 2020;18:87.

134 Nazi I, Kelton JG, Larché $\mathrm{M}$, et al. The effect of rituximab on vaccine responses in patients with immune thrombocytopenia. Blood 2013;122:1946-53.

135 Cagigi A, Loré K. Immune responses induced by mRNA vaccination in mice, monkeys and humans. Vaccines 2021;9:61.

136 Bettini E, Locci M. SARS-CoV-2 mRNA vaccines: immunological mechanism and beyond. Vaccines 2021;9:147.

137 Cronstein BN, Aune TM. Methotrexate and its mechanisms of action in inflammatory arthritis. Nat Rev Rheumatol 2020;16:145-54.

138 Allison AC, Eugui EM. Mycophenolate mofetil and its mechanisms of action. Immunopharmacology 2000;47:85-118.

139 Moreland L, Bate G, Kirkpatrick P. Abatacept. Nat Rev Drug Discov 2006;5:185-6.

140 O'Shea JJ, Gadina M. Selective Janus kinase inhibitors come of age. Nat Rev Rheumatol 2019;15:74-5.

141 Cragg MS, Walshe CA, Ivanov AO, et al. The biology of CD20 and its potential as a target for mAb therapy. Curr Dir Autoimmun 2005;8:140-74.

142 Engel P, Gómez-Puerta JA, Ramos-Casals M, et al. Therapeutic targeting of B cells for rheumatic autoimmune diseases. Pharmacol Rev 2011;63:127-56. 